\title{
Genetic and phenotypic diversity characterization of natural populations of the parasitoid Parvilucifera sinerae
}

\author{
Marta Turon $^{1}$, Elisabet Alacid ${ }^{1}$, Rosa Isabel Figueroa ${ }^{2}$, Albert Reñé ${ }^{1}$, Isabel Ferrera ${ }^{1}$, \\ Isabel Bravo ${ }^{3}$, Isabel Ramilo ${ }^{3}$, Esther Garcés ${ }^{1, *}$ \\ ${ }^{1}$ Departament de Biologia Marina i Oceanografia, Institut de Ciències del Mar, CSIC, Pg. Marítim de la Barceloneta 37-49, \\ 08003 Barcelona, Spain \\ ${ }^{2}$ Department of Biology, Lund University, Box 118, 22100 Lund, Sweden \\ ${ }^{3}$ Centro Oceanográfico de Vigo, IEO (Instituto Español de Oceanografía), Subida a Radio Faro 50, 36390 Vigo, Spain
}

\begin{abstract}
Parasites exert important top-down control of their host populations. The host-parasite system formed by Alexandrium minutum (Dinophyceae) and Parvilucifera sinerae (Perkinsozoa) offers an opportunity to advance our knowledge of parasitism in planktonic communities. In this study, DNA extracted from 73 clonal strains of $P$. sinerae, from 10 different locations along the Atlantic and Mediterranean coasts, was used to genetically characterize this parasitoid at the species level. All strains showed identical sequences of the small and large subunits and internal transcribed spacer of the ribosomal RNA, as well as of the $\beta$-tubulin genes. However, the phenotypical characterization showed variability in terms of host invasion, zoospore success, maturation time, half-maximal infection, and infection rate. This characterization grouped the strains within 3 phenotypic types distinguished by virulence traits. A particular virulence pattern could not be ascribed to host-cell bloom appearance or to the location or year of parasite-strain isolation; rather, some parasitoid strains from the same bloom significantly differed in their virulence traits. Identical markers such as ITS and $\beta$-tubulin genes of $P$. sinerae strains from different geographic areas and from different years precludes their use in assessing intra-specific diversity and could indicate a recent dispersion of this species.
\end{abstract}

KEY WORDS: Apicomplexa - Dinoflagellates - Host-parasite interactions - Parasitoids . Perkinsozoa $\cdot$ Ribosomal marker

\section{INTRODUCTION}

Parasites play fundamental roles in marine ecosystems by regulating host population diversity and density and are therefore relevant in modifying food webs (Poulin \& Thomas 1999, Park et al. 2004, Wolinska et al. 2009, Skovgaard 2014). Parasites interact with their hosts in numerous ways. They modify the frequency distribution of phenotypic traits and the sex ratio of their hosts (Poulin \& Thomas 1999), alter the geographic boundaries of species distribution

\footnotetext{
${ }^{*}$ Corresponding author: esther@icm.csic.es
}

(Park et al. 2004), are important determinants of host speciation (Thompson 1987), and influence host biology and behavior (Park et al. 2004), including swimming pattern, photosynthetic activity (Coats \& Park 2002), and cyst formation (Toth et al. 2004, Chambouvet et al. 2011). Moreover, those species that are parasitoids, in which completion of their life cycle involves killing of their respective host, are important in controlling the size of host populations.

The use of parasites, and of parasitoids in particular, has been considered in the biological control of nox-

() The authors 2015. Open Access under Creative Commons by Attribution Licence. Use, distribution and reproduction are unrestricted. Authors and original publication must be credited. 
ious hosts. Of particular interest is the use of marine microparasites in the mitigation of harmful algal blooms (HABs) (Chambouvet et al. 2008, Montagnes et al. 2008, Mazzillo et al. 2011). However, a prerequisite for the successful application of this approach in HAB control is a detailed understanding of parasite effects on marine plankton, host-parasite population dynamics, and the variability within parasite populations that interact with HAB-forming species. For example, the strength of the selection pressure exerted by parasitism can differ substantially within a given system, depending on the intra-population variability of the parasite and its host. Hence, in the modeling of host-parasite systems, the 2 components must be thoroughly characterized, both genetically and phenotypically. Nevertheless, intra-species variability within parasite populations has been examined only for the Amoebophrya ceratii complex, members of which parasitize a wide range of photosynthetic and heterotrophic dinoflagellates. Those studies examined differences in generation time, reproduction, infectivity, survival, and host specificity (Yih \& Coats 2000, Coats \& Park 2002, Park et al. 2013).

Defining species, in the case of microparasites, is intricate since the traditional 'biological species concept' may not adequately describe a large number of parasitic species (Lymbery 1992). At present, many species of microorganisms have been described on the basis of phenotypic characteristics. However, progress in molecular techniques has been of great help for establishing the degree of phylogenetic divergence that constitutes the border between populations (or clades) and different species. However, this limit is not equal across different phyla, and thus each group of organisms requires a specific study.

Molecular characterization of marine protists, including species-level identifications, has commonly been achieved using the genes encoding the small (18S) and large (28S) subunits of ribosomal RNA (rRNA), because of their high level of conservation within species (Edvardsen et al. 2003, Lohr et al. 2010). However, when these coding regions do not provide sufficient resolution, the typically higher genetic variability of the non-coding ribosomal internal transcribed spacers ITS 1 and ITS 2 can be valuable in species- or population-level studies, as shown in the discrimination of species and clades of several parasites (e.g. Collins \& Allssopp 1999, Robledo et al. 2000, Brown et al. 2004, Skovgaard et al. 2005, Lohr et al. 2010). Nonetheless, ITS sequences do not always provide sufficient resolution (Logares et al. 2008), necessitating the use of genes with potentially faster evolution rates, such as mitochondrial genes
(Lin et al. 2002, Masuda et al. 2010, Zhang et al. 2011, Orr et al. 2012) and those encoding heat-shock proteins, $\beta$ - and $\alpha$-tubulin, and actin genes (Reece et al. 1997, Fast et al. 2002, Leander 2003, Saldarriaga 2003) to infer phylogenetic relationships among closely related protists. However, with the demonstration that some organisms apparently identical by genetic characterization, especially in their rRNA genes, are in fact different strains or even different species, as evidenced in morphological, physiological, and geographical studies (Robledo et al. 1999, Connell 2000, Loret et al. 2002, Tengs et al. 2003), it has become clear that proper species identification must be based on both genetic and phenotypic characterization.

The focus of our study was the parasitoid Parvilucifera sinerae (Figueroa et al. 2008), which infects a broad range of dinoflagellate species (Garcés et al. 2013). Parvilucifera belongs to the Perkinsozoa group, together with the genus Perkinsus, and clusters within the superphylum of Alveolates (Figueroa et al. 2008). Organisms belonging to this group are endoparasites that share characteristics with dinoflagellates and apicomplexans (Garcés \& Hoppenrath 2010). To date, 4 species belonging to the genus Parvilucifera have been described: P. infectans (Norén et al. 1999), P. sinerae (Figueroa et al. 2008), P. prorocentri (Leander \& Hoppenrath 2008), and most recently, $P$. rostrata (Lepelletier et al. 2014). Among the described Parvilucifera species, genetic and phenotypic differences between $P$. sinerae and $P$. infectans are still in discussion; thus, a better characterization is required.

As with other parasitoids, an understanding of the role of $P$. sinerae in food webs requires the identification and characterization of the life history of this species, including its different stages and their physiological features. Preliminary studies have demonstrated high levels of variability in terms of parasitoid virulence within different strains of $P$. sinerae (Råberg et al. 2014). This led us to hypothesize that strains of the same species may nonetheless vary dramatically in their physiological characteristics, which has important implications in the use of parasitoids to control HABs.

In this study, we phylogenetically characterized for the first time different strains of $P$. sinerae from the Atlantic and Mediterranean coasts based on their small subunit (SSU) and large subunit (LSU) rRNA and other commonly variable genes, such as the ITS region of the rRNA gene, and the $\beta$-tubulin gene. Further, we characterized the phenotypic intraspecies variability of several strains of $P$. sinerae. Our 
results provide further molecular information for the phylogenetic position of the species, and physiological traits of the different strains, but genetic variability was not observed for these strains. The implications of our findings are discussed herein.

\section{MATERIALS AND METHODS}

\section{Host and parasitoid strains and culture maintenance}

The experiments were conducted using clonal strains of the host Alexandrium sp. (Table 1), obtained from the culture collection of the Centro Oceanográfico de Vigo (CCVIEO, www.vi.ieo.es). Non-axenic culture stocks were grown in $450 \mathrm{ml}$ polystyrene tissue culture flasks filled with L1 medium (Guillard 1995) adjusted to a salinity of 36, at $20 \pm 1^{\circ} \mathrm{C}, 90 \mu \mathrm{mol}$ photons $\mathrm{m}^{-2} \mathrm{~s}^{-1}$, and a $12: 12 \mathrm{~h}$ photoperiod. Stock cultures were maintained in the exponential phase of growth.

Clonal strains of the parasitoid Parvilucifera sinerae were isolated during the years 2009, 2011, 2012, and 2013 from 10 different locations off the Spanish coast: 6 sites in the Mediterranean Sea and 4 sites in the Atlantic Ocean (Table 1). Initial samples were kept at $4^{\circ} \mathrm{C}$ for $1 \mathrm{~d}$ before isolation to make sure that sporangia would not hatch so that free-living zoospores, which are more difficult to detect under a microscope, would not be present in the sample during the isolation step. $P$. sinerae clones were obtained by pipetting a single sporangium from the field sample. The sporangium was transferred through 3 consecutive water drops to assure that only 1 sporangium was taken, and finally transferred to a 96-well tissue

Table 1. Clonal strains of Parvilucifera sinerae cultured in this study. Grey shading indicates strains used in the phenotypic analysis. X indicates the clones from which large subunit (LSU), small subunit (SSU), and internal transcribed spacer (ITS) rDNA and $\beta$-tubulin (TUB) sequences were obtained. The host strains are the ones used for isolation, maintenance, and experimental trials. A. min: Alexandrium minutum, A. tam: A. tamarense

\begin{tabular}{|c|c|c|c|c|c|c|c|c|}
\hline Strain & Isolation date & Isolation site & Coast & Host strain & LSU & SSU & ITS & TUB \\
\hline $\mathrm{P} 1^{\mathrm{a}}$ & 09/01/2009 & Vilanova & Mediterranean & AMP4 (A. min) & $\mathrm{X}$ & $\mathrm{X}$ & $\mathrm{X}$ & \\
\hline $\mathrm{P} 2$ & 07/05/2011 & Vilanova & Mediterranean & AMP4 (A. min) & $\mathrm{X}$ & $\mathrm{X}$ & $\mathrm{X}$ & \\
\hline $\mathrm{P} 4$ & $07 / 05 / 2011$ & Vilanova & Mediterranean & AMP4 (A. min) & $\mathrm{X}$ & & $\mathrm{X}$ & $\mathrm{X}$ \\
\hline $\mathrm{P} 10^{\mathrm{a}}$ & $07 / 05 / 2011$ & Vilanova & Mediterranean & AMP4 (A. min) & $\mathrm{X}$ & & $\mathrm{X}$ & $\mathrm{X}$ \\
\hline P12 & 07/05/2011 & Vilanova & Mediterranean & AMP4 (A. min) & $\mathrm{X}$ & & & \\
\hline P15 & 07/05/2011 & Vilanova & Mediterranean & AMP4 (A. min) & $\mathrm{X}$ & $\mathrm{X}$ & & $\mathrm{X}$ \\
\hline P26 & 03/06/2011 & Vilanova & Mediterranean & AMP4 (A. min) & $\mathrm{X}$ & $\mathrm{X}$ & & $\mathrm{X}$ \\
\hline $\mathrm{P} 13^{\mathrm{a}}$ & $23 / 06 / 2011$ & Vilanova & Mediterranean & AMP4 (A. min) & $\mathrm{X}$ & & & \\
\hline P29 & 10/02/2011 & Arenys & Mediterranean & AMP4 (A. min) & $\mathrm{X}$ & & & \\
\hline P9 & 05/03/2011 & Arenys & Mediterranean & AMP4 (A. min) & $\mathrm{X}$ & & $\mathrm{X}$ & $\mathrm{X}$ \\
\hline P18 & 05/03/2011 & Arenys & Mediterranean & AMP4 (A. min) & $\mathrm{X}$ & & & \\
\hline P3 & $19 / 03 / 2011$ & Arenys & Mediterranean & AMP4 (A. min) & $\mathrm{X}$ & $\mathrm{X}$ & $\mathrm{X}$ & $\mathrm{X}$ \\
\hline P31 & $19 / 03 / 2011$ & Arenys & Mediterranean & AMP4 (A. $\min )$ & $\mathrm{X}$ & & $\mathrm{X}$ & \\
\hline P14 & $26 / 03 / 2011$ & Arenys & Mediterranean & AMP4 (A. min) & $\mathrm{X}$ & $\mathrm{X}$ & & \\
\hline P19 & $26 / 03 / 2011$ & Arenys & Mediterranean & AMP4 (A. min) & $\mathrm{X}$ & & & $\mathrm{X}$ \\
\hline P21 & $26 / 03 / 2011$ & Arenys & Mediterranean & AMP4 (A. min) & $\mathrm{X}$ & $\mathrm{X}$ & & $\mathrm{X}$ \\
\hline P23 & $26 / 03 / 2011$ & Arenys & Mediterranean & AMP4 (A. min) & & $\mathrm{X}$ & & $\mathrm{X}$ \\
\hline P25 & 26/03/2011 & Arenys & Mediterranean & AMP4 (A. min) & $\mathrm{X}$ & $\mathrm{X}$ & & \\
\hline P33 & $26 / 03 / 2011$ & Arenys & Mediterranean & AMP4 (A. min) & $\mathrm{X}$ & & $\mathrm{X}$ & $\mathrm{X}$ \\
\hline P30 & $31 / 03 / 2011$ & Arenys & Mediterranean & AMP4 (A. min) & $\mathrm{X}$ & & & \\
\hline P22 & $10 / 02 / 2012$ & Arenys & Mediterranean & AMP4 (A. min) & & $\mathrm{X}$ & & $\mathrm{X}$ \\
\hline P6 & $15 / 02 / 2012$ & Arenys & Mediterranean & AMP4 (A. min) & $\mathrm{X}$ & $\mathrm{X}$ & & $\mathrm{X}$ \\
\hline P17 & $19 / 03 / 2012$ & Arenys & Mediterranean & AMP4 (A. min) & $\mathrm{X}$ & & & \\
\hline P32 & 19/03/2012 & Arenys & Mediterranean & AMP4 (A. min) & $\mathrm{X}$ & & & \\
\hline P37 & 19/03/2012 & Arenys & Mediterranean & AMP4 (A. min) & $\mathrm{X}$ & & $\mathrm{X}$ & $\mathrm{X}$ \\
\hline P38 & 19/03/2012 & Arenys & Mediterranean & AMP4 (A. min) & $\mathrm{X}$ & & & \\
\hline P61 & $15 / 04 / 2012$ & Arenys & Mediterranean & AMP4 (A. min) & & $\mathrm{X}$ & & $\mathrm{X}$ \\
\hline P62 & $15 / 04 / 2012$ & Arenys & Mediterranean & AMP4 (A. min) & $\mathrm{X}$ & $\mathrm{X}$ & & \\
\hline P63 & 15/04/2012 & Arenys & Mediterranean & AMP4 (A. min) & $\mathrm{X}$ & $\mathrm{X}$ & & \\
\hline P64 & 15/04/2012 & Arenys & Mediterranean & AMP4 (A. min) & $\mathrm{X}$ & $\mathrm{X}$ & & $\mathrm{X}$ \\
\hline P7 & $23 / 07 / 2012$ & Arenys & Mediterranean & AMP4 (A. $\mathrm{min})$ & $\mathrm{X}$ & & & $\mathrm{X}$ \\
\hline P70 & $04 / 03 / 2013$ & Arenys & Mediterranean & AMP4 (A. min) & $\mathrm{X}$ & & $\mathrm{X}$ & $\mathrm{X}$ \\
\hline P71 & 04/03/2013 & Arenys & Mediterranean & AMP4 (A. min) & $\mathrm{X}$ & & & $\mathrm{X}$ \\
\hline
\end{tabular}


Table 1 (continued)

\begin{tabular}{|c|c|c|c|c|c|c|c|c|}
\hline Strain & Isolation date & Isolation site & Coast & Host strain & LSU & SSU & ITS & TUB \\
\hline P72 & 04/03/2013 & Arenys & Mediterranean & AMP4 (A. min) & $\mathrm{X}$ & & & \\
\hline P73 & $04 / 03 / 2013$ & Arenys & Mediterranean & AMP4 (A. min) & $\mathrm{X}$ & $\mathrm{X}$ & $\mathrm{X}$ & $\mathrm{X}$ \\
\hline P66 & $26 / 03 / 2013$ & Arenys & Mediterranean & AMP4 (A. min) & & $\mathrm{X}$ & & $\mathrm{X}$ \\
\hline P67 & $26 / 03 / 2013$ & Arenys & Mediterranean & AMP4 (A. min) & $\mathrm{X}$ & & & $\mathrm{X}$ \\
\hline P68 & $26 / 03 / 2013$ & Arenys & Mediterranean & AMP4 (A. min) & $\mathrm{X}$ & & & $\mathrm{X}$ \\
\hline P58 & $26 / 03 / 2013$ & Arenys & Mediterranean & AMP4 (A. min) & $\mathrm{X}$ & $X$ & $X$ & $\mathrm{X}$ \\
\hline P69 & $26 / 03 / 2013$ & Arenys & Mediterranean & AMP4 (A. min) & $\mathrm{X}$ & & $\mathrm{X}$ & $\mathrm{X}$ \\
\hline P53 & $28 / 03 / 2013$ & Arenys & Mediterranean & AMP4 (A. min) & $\mathrm{X}$ & $X$ & $\mathrm{X}$ & $\mathrm{X}$ \\
\hline P54 & $28 / 03 / 2013$ & Arenys & Mediterranean & AMP4 (A. min) & $\mathrm{X}$ & $\mathrm{X}$ & $\mathrm{X}$ & $\mathrm{X}$ \\
\hline P55 & $28 / 03 / 2013$ & Arenys & Mediterranean & AMP4 (A. $\min )$ & $\mathrm{X}$ & $\mathrm{X}$ & $\mathrm{X}$ & $\mathrm{X}$ \\
\hline P56 & $28 / 03 / 2013$ & Arenys & Mediterranean & AMP4 (A. min) & $\mathrm{X}$ & $\mathrm{X}$ & $\mathrm{X}$ & $\mathrm{X}$ \\
\hline P57 & $28 / 03 / 2013$ & Arenys & Mediterranean & AMP4 (A. min) & & $\mathrm{X}$ & $\mathrm{X}$ & $\mathrm{X}$ \\
\hline P59 & $28 / 03 / 2013$ & Arenys & Mediterranean & AMP4 (A. min) & $\mathrm{X}$ & $\mathrm{X}$ & $\mathrm{X}$ & $\mathrm{X}$ \\
\hline P60 & $28 / 03 / 2013$ & Arenys & Mediterranean & AMP4 (A. min) & $\mathrm{X}$ & $\mathrm{X}$ & $\mathrm{X}$ & $\mathrm{X}$ \\
\hline P65 & $28 / 03 / 2013$ & Arenys & Mediterranean & AMP4 (A. min) & $\mathrm{X}$ & $\mathrm{X}$ & $\mathrm{X}$ & $\mathrm{X}$ \\
\hline P52 & $08 / 04 / 2013$ & Arenys & Mediterranean & AMP4 (A. min) & $\mathrm{X}$ & $\mathrm{X}$ & $\mathrm{X}$ & $\mathrm{X}$ \\
\hline P16 & $15 / 05 / 2011$ & Estartit & Mediterranean & AMP4 (A. min) & $\mathrm{X}$ & $\mathrm{X}$ & & $\mathrm{X}$ \\
\hline P34 & $15 / 05 / 2011$ & Estartit & Mediterranean & AMP4 (A. min) & $\mathrm{X}$ & & & $\mathrm{X}$ \\
\hline $\mathrm{P} 27$ & $21 / 05 / 2011$ & Estartit & Mediterranean & AMP4 (A. min) & $\mathrm{X}$ & & & $\mathrm{X}$ \\
\hline P8 & $21 / 05 / 2012$ & Estartit & Mediterranean & AMP4 (A. $\min )$ & $\mathrm{X}$ & & & \\
\hline $\mathrm{P} 11^{\mathrm{a}}$ & $03 / 06 / 2011$ & Barcelona & Mediterranean & AMP4 (A. $\min )$ & $\mathrm{X}$ & $\mathrm{X}$ & & \\
\hline $\mathrm{P} 20^{\mathrm{a}}$ & 06/06/2011 & Cambrils & Mediterranean & AMP4 (A. min) & $\mathrm{X}$ & $\mathrm{X}$ & & \\
\hline P24 & 06/06/2011 & Cambrils & Mediterranean & AMP4 (A. min) & $\mathrm{X}$ & $\mathrm{X}$ & & \\
\hline P28 & $20 / 06 / 2011$ & Tarragona & Mediterranean & AMP4 (A. min) & $\mathrm{X}$ & $\mathrm{X}$ & & $\mathrm{X}$ \\
\hline P5 & $27 / 06 / 2011$ & Coruña & Atlantic & Min 3 (A. min) & $\mathrm{X}$ & & & $\mathrm{X}$ \\
\hline P35 & $27 / 06 / 2011$ & Coruña & Atlantic & Min 3 (A. min) & $\mathrm{X}$ & & & \\
\hline P36 & $27 / 06 / 2011$ & Coruña & Atlantic & Min 3 (A. min) & $\mathrm{X}$ & $\mathrm{X}$ & $\mathrm{X}$ & \\
\hline P45 & $27 / 06 / 2011$ & Coruña & Atlantic & PE1V (A. tam) & $\mathrm{X}$ & & & $\mathrm{X}$ \\
\hline P51 & $27 / 06 / 2011$ & Coruña & Atlantic & PE1V (A. tam) & $\mathrm{X}$ & & & $\mathrm{X}$ \\
\hline P41 & $07 / 06 / 2011$ & Baiona & Atlantic & $\operatorname{PE} 1 \mathrm{~V}$ (A. tam) & $\mathrm{X}$ & & & $\mathrm{X}$ \\
\hline $\mathrm{P} 43$ & $20 / 10 / 2011$ & Baiona & Atlantic & $\mathrm{H} 4$ (A. min) & $\mathrm{X}$ & & & $\mathrm{X}$ \\
\hline P39 & $30 / 03 / 2012$ & Baiona & Atlantic & H4 (A. min) & $\mathrm{X}$ & & & $\mathrm{X}$ \\
\hline $\mathrm{P} 42$ & $30 / 03 / 2012$ & Baiona & Atlantic & H4 (A. min) & $\mathrm{X}$ & & & \\
\hline P44 & $30 / 03 / 2012$ & Baiona & Atlantic & $\mathrm{H} 4$ (A. min) & $\mathrm{X}$ & & & \\
\hline P40 & $03 / 05 / 2012$ & Bilbao & Atlantic & H4 (A. min) & $\mathrm{X}$ & & & \\
\hline P46 & $03 / 05 / 2012$ & Bilbao & Atlantic & PE1V (A. tam) & $\mathrm{X}$ & & & X \\
\hline P47 & $03 / 05 / 2012$ & Bilbao & Atlantic & H4 (A. min) & $\mathrm{X}$ & & & $\mathrm{X}$ \\
\hline P49 & $03 / 05 / 2012$ & Bilbao & Atlantic & $\operatorname{PE1V}(A . t a m)$ & $\mathrm{X}$ & & & \\
\hline $\mathrm{P} 50$ & $03 / 05 / 2012$ & Bilbao & Atlantic & PE1V (A. tam) & $\mathrm{X}$ & & & $\mathrm{X}$ \\
\hline P48 & $27 / 06 / 2012$ & Aveiro & Atlantic & $\mathrm{H} 4$ (A. $\min )$ & $\mathrm{X}$ & & & \\
\hline
\end{tabular}

culture plate (Iwaki) containing sterile seawater. After microscopic confirmation, the single sporangium was transferred to an exponentially growing host culture. Parasitoid cultures were propagated by transferring aliquots of mature sporangia (20-25) every $6-7 \mathrm{~d}$ into $16 \mathrm{~mm}$ sterile polystyrene Petri dishes (Iwaki) containing an uninfected stock culture of exponentially growing Alexandrium sp. Four different clonal strains of Alexandrium sp. (Table 1) were used as hosts to allow optimal isolation, infection, propagation, and maintenance of the parasitoid cultures (data not shown). Briefly, A. minutum strain AMP4 was used to obtain clonal strains of parasitoids from the Mediterranean Sea, whereas A. minutum strains MIN3 and H4 and A. tamarense strain PE1V were used to obtain $P$. sinerae from the Atlantic Ocean (Table 1). The cultures were incubated for 10 $\mathrm{d}$ (on average), and their infection cycle was followed by daily observations under the microscope. Infected cultures were treated with $\mathrm{GeO}_{2}$ ( $6 \mathrm{ng} \mathrm{l^{-1 }}$ culture) if contamination by diatoms was detected. Contamination by diatoms or other small picoplanktonic species could have occurred during the isolation step if they were attached to the sporangia and difficult to detect under microscope observation. However, contamination by other Parvilucifera strains during the isolation step was dismissed because of the accurate cleaning procedure by transferring through 3 water drops dur- 
ing which the presence of other possible sporangia would have been detected. The clones were collected into sterile $50 \mathrm{ml}$ tubes (Falcon) after all dinoflagellates had been infected and only mature parasitoid sporangia were present. The samples were stored at $4^{\circ} \mathrm{C}$ in the dark; under these conditions, the viability of the infected cultures is maintained for at least 4 mo (data not shown). The parasitoids were reactivated for use in the experiments by the addition of an exponentially growing host culture to the sporangia culture. These cultures were incubated at $20 \pm 1^{\circ} \mathrm{C}$ in the light under the same conditions as described above.

\section{Genetic characterization}

\section{DNA extraction, $\mathrm{PCR}$, and sequencing}

Samples of mature sporangia of $P$. sinerae without dinoflagellate cells were treated with antibiotics to prevent bacterial contamination, adding $1.5 \mathrm{ml}$ of a $100 \mathrm{ml}$ stock solution containing $0.3 \mathrm{~g}$ of penicillin, $1 \mathrm{~g}$ of neomycin, and $5 \mathrm{~g}$ of streptomycin to each $30 \mathrm{ml}$ sample. The samples were stored for $4 \mathrm{~d}$ in the dark at $4^{\circ} \mathrm{C}$ and then filtered first through a $10 \mu \mathrm{m}$ filter to remove bacterial detritus and next collected into $50 \mathrm{ml}$ tubes. After centrifugation of the samples for $20 \mathrm{~min}$ at $3000 \times g$, the supernatant was discarded and the remaining pellet was transferred to a $1.5 \mathrm{ml}$ sterile Eppendorf tube and stored at $-80^{\circ} \mathrm{C}$.

DNA from 73 samples (Table 1) was extracted using the DNeasy plant mini kit (Qiagen). Nuclear ribosomal DNA sequences corresponding to the ITS, SSU, and LSU fragments were amplified and sequenced, as were the sequences corresponding to the $\beta$-tubulin gene. PCR amplifications were conducted in $50 \mu \mathrm{l}$ reactions containing $5 \mathrm{ng}$ of template genomic DNA, $5 \mu \mathrm{l}$ of $10 \times$ PCR buffer (containing $\left.1.5 \mathrm{mM} \mathrm{MgCl}_{2}\right), 1 \mu \mathrm{l}$ of dNTP mix $(10 \mathrm{mM}), 4 \mu \mathrm{l}$ of each primer (10 mM, $2.5 \mu \mathrm{l}$ for SSU), $0.5 \mu \mathrm{l}$ of Taq DNA polymerase $\left(5 \mathrm{U} \mathrm{\mu l}^{-1}, 0.25 \mu \mathrm{l}\right.$ for LSU; Qiagen), and for ITS and $\beta$-tubulin, $1 \mu \mathrm{l}$ of $\mathrm{MgCl}_{2}(25 \mathrm{mM})$ and for $\beta$-tubulin $3 \mu \mathrm{l}$ of bovine serum albumin. The PCR conditions and the primers used for each region are presented in Table A1 in the Appendix. Aliquots $(10 \mu \mathrm{l})$ of the PCR products were electrophoresed for 20 to $30 \mathrm{~min}$ at $120 \mathrm{~V}$ in a $1.2 \%$ agarose gel and then visualized under UV illumination. The remainder of the reaction mix $(40 \mu l)$ was stored at $-20^{\circ} \mathrm{C}$ and later used for sequencing. Purification and sequencing were carried out by an external service (Genoscreen, France) using both forward and reverse primers for all genes, and internal primers for the SSU gene, and a $3730 \mathrm{XL}$ DNA sequencer.

\section{Phylogenetic analysis}

The obtained sequences were aligned with related sequences available in GenBank using MAFFT v.6 (Katoh et al. 2002) and manually checked with Bio Edit v.7.0.5 (Hall 1999), yielding final alignments of 1898 positions for the SSU region, 1504 positions for the LSU region, and 960 positions for the ITS region. For the $\beta$-tubulin, nucleotide sequences were translated (Geneious v.6.0.5) into amino acids, and a final alignment of 387 residues was obtained. Phylogenetic relationships were inferred using the maximum-likelihood (ML) and Bayesian inference methods. For the former, the GTRGAMMA evolution model was selected using MODELTEST (Darriba et al. 2012) for ribosomal genes. PROTGAMMAJTT was the evolution model selected, using ProtTest (Darriba et al. 2011) for $\beta$-tubulin. Both models were used on Randomized Accelerated Maximum Likelihood (RAxML) v.7.0.4 (Stamatakis 2006). Repeated runs on distinct starting trees were carried out to select the tree with the best topology (the one with the greatest likelihood of 1000 alternative trees). Bootstrap ML analysis was done with 1000 pseudoreplicates, and the consensus tree was computed with RaxML. Bayesian inference was performed with MrBayes v.3.2 (Ronquist et al. 2012), run with a GTR model in which the rates were set to gamma. Each analysis was performed using 4 Markov chain Monte Carlo chains, with 1 million cycles for each chain. The consensus tree was created from post-burn-in trees, and the Bayesian posterior probabilities of each clade were examined.

\section{Phenotypic characterization}

Twelve of the 73 P. sinerae strains were used for the phenotypic study (Table 1). All selected strains were isolated from the Mediterranean area using the same host strain, and 6 of them were further selected because they already showed differences in their host range, as determined in preliminary infection experiments (Råberg et al. 2014). Phenotypic analysis characterized strain variability in host invasion, infection rate, half-maximal infection $\left(K_{m}\right)$, maximum infection, and zoospore success, as described in the following section. 
Strain variability in host invasion, infection rate, $K_{m}$, and maximum infection

The infection capacity of a parasitoid was estimated based on the rate at which it invaded the host strain. The invasion rate was determined by mixing motile cells of A. minutum (AMP4) with the 12 different strains of the parasitoid $P$. sinerae (Table 1) in $2 \mathrm{ml}$ phytoplankton chambers and then monitoring the infection process over time. The selected 12 strains of the parasitoid $P$. sinerae were initially isolated and maintained in the AMP4 host. Host cells were considered to be infected when they became non-motile, which caused them to sink to the bottom of the experimental chamber. Special attention was paid to the formation of ecdysal cysts of A. minutum, observing athecate and round cells. However, they were not detected during the experiments.

Experimental mixtures were prepared in quadruplicate $2 \mathrm{ml}$ counting chambers by pipetting aliquots of mature $P$. sinerae sporangia stock into a host culture containing 5000 cells $\mathrm{ml}^{-1}$. The size of the parasitoid inoculum was adjusted to obtain a zoospore:host ratio of 20:1 in order to adjust parasitoid and host concentrations for all trials. The concentration of inoculated zoospores was estimated based on the assumption that 1 mature sporangium of A. minutum host contains 250 zoospores (Garcés et al. 2013). Uninfected $A$. minutum cultures were used as the control in all experiments.

A. minutum invasion rates were determined in vivo by counting non-motile cells every 10 min during the first $30 \mathrm{~min}$ and every $20 \mathrm{~min}$ thereafter for a total of $90 \mathrm{~min}$. Three replicates were counted simultaneously under an inverted microscope (either LeicaLeitz DM IRB, Leica-Leitz DM IL, Leica Microsystems; or Nikon DIAPHOT, Nippon Kogaku KK, Japan Optics).

Data obtained in the infectivity experiment were fitted to the Michaelis-Menten equation using Kaleidagraph (version 4.1.1). For strains whose data fit the curve well $\left(\mathrm{R}^{2}>0.9\right)$, both the $K_{m}$ and the maximum infection level were calculated. The latter is the point at which the curve reaches saturation, i.e. the number of host cells invaded by the parasitoid is assumed to have reached a maximum. The $K_{m}$ corresponds to the time at which the infection level has reached half of the maximum infection level.

The infection rates determined for the 12 strains corresponded to the slope of the initial linear portion of the fitted curve indicating how fast the parasite strain achieves host-cell saturation. Infection rates were expressed as the number of invaded cells $\mathrm{ml}^{-1}$.
Strain variability in the zoospore success rate

Zoospore infection of its host is the first step in the life cycle of $P$. sinerae. The zoospore success rate, one of the parameters evaluated in this study, is defined as the number of zoospores from 1 sporangium that successfully infect a host cell. It is calculated by dividing the number of invaded host cells at a given time (in our study, $90 \mathrm{~min}$ ) by the number of zoospores inoculated, assuming that each host cell is invaded by a single zoospore. Double or several infections in a single host cell were not considered for this work, since they are seldom observed in the case of $A$. minutum host (Garcés et al. 2013). In the present work, the zoospore success rate was assessed for a host population density of 5000 cells $\mathrm{ml}^{-1}$.

\section{Statistical similarity analysis}

Similarities in the data obtained from the different strains of $P$. sinerae were determined using PRIMER 6.1.2 (Clarke \& Gorley 2006). Group average clustering and a SIMPROF test were performed taking into account the mean maximum infection and $K_{m}$, the infection rates, and the zoospore success rate. The level of host invasion at 90 min was not included in the analysis because of its high correlation $(C=0.9)$ with the maximum infection values. The resemblance determination was based on the Bray-Curtis similarity, and a similarity boundary (90) was estimated. ANOSIM, multi-dimensional scaling (MDS), and SIMPER analyses were performed as well in PRIMER.

Strain variability in sporangium germination and maturation time

The percentage of germinating sporangia and the time required for $P$. sinerae zoospore maturation were assessed in vivo using the same strains investigated in the infectivity experiment (Table 1). In our experimental design, mature sporangia were those that hatched within a period of minutes after exposure to host exudates.

Three replicates of each $P$. sinerae strain were incubated as described above. When $>80 \%$ of the sporangia had reached maturity, 3 aliquots of each replicate were transferred to new medium containing $A$. minutum exudates, which were prepared taking $5 \mathrm{ml}$ of a host culture with a syringe and filtering 
them through a $0.2 \mu \mathrm{m}$ filter where the cells were retained. The inoculum size of the parasitoid was adjusted to achieve a zoospore:host ratio of 20:1. Sporangia were quantified using a Leica-Leitz DM IL inverted microscope (Leica Microsystems) both at time 0 and after 90 min of incubation with $A$. minutum exudates. The measurements were repeated daily since mature sporangia continued to be observed even when $>80 \%$ had germinated. The loss of sporangia between 0 and $90 \mathrm{~min}$ was assumed to be the percentage of mature sporangia that had hatched in response to the presence of A. minutum exudates.

\section{RESULTS}

\section{Genetic analysis}

This is the first study to report the LSU, ITS, and $\beta$ tubulin gene sequences of Parvilucifera sinerae: 3 markers that indicate the phylogenetic position of this parasitoid species.

From the 73 strains analyzed, 68 partial LSU rRNA sequences of $\sim 648 \mathrm{bp}, 33$ complete SSU rRNA sequences of $\sim 1706 \mathrm{bp}, 22$ ITS rRNA sequences of $695 \mathrm{bp}$, and $46 \beta$-tubulin sequences of $\sim 970 \mathrm{bp} \mathrm{(323}$ amino acids) were obtained (Table 1 ). The sequences for each of the markers, i.e. the different rRNA regions and the $\beta$-tubulin gene, were $100 \%$ identical in all strains. The consensus sequence of each region was deposited in GenBank under accession numbers KM878665, KM878666, KM878667, and KM878668.

Phylogenies based on the LSU rRNA (Fig. 1), ITS (data not shown), and $\beta$-tubulin (Fig. 2) gene sequences provided congruent tree topologies that coincided with the one already published for the SSU region (Figueroa et al. 2008). However, the relationship between Parvilucifera and Perkinsus clustering together within the Perkinsozoa is not yet well resolved in our phylogenetic trees (Figs. 1 \& 2). In all cases, Parvilucifera and Perkinsus species clustered together as a clade corresponding to Perkinsozoa (Figs. 1 \& 2), although with low bootstrap support.

Table 2 shows the percentage of genetic similarities between the rRNA sequences of $P$. sinerae and those of other Parvilucifera species. For the SSU rRNA region, our sequence was essentially the same as the $P$. sinerae sequence reported by Figueroa et al. (2008), but it differed from those of P. rostrata (Lepelletier et al. 2014) and P. prorocentri (Hoppenrath \& Leander 2009), with $86.6 \%$ and $79.4 \%$ identical bases, respectively. In the case of P. infectans, our sequence had $98.7 \%$ similarity with the SSU rRNA sequence reported by Norén et al. (1999) (AF133909), but it was $100 \%$ identical to the one reported by Lepelletier et al. (2014) (KF359485). For the LSU rRNA sequence, our sequence was $100 \%$ identical to that of $P$. infectans (KF359486) (Lepelletier et al. 2014), but it differed from the sequence of $P$. rostrata (KF359484) (81.3\% similarity). The same pattern was found in the ITS region, in which higher levels of divergence were observed within different species of the Parvilucifera genus. Again, the difference between P. rostrata (KF359483) and $P$. sinerae (KM878665), which differed in more than $50 \%$ of their base pairs in the ITS region, is clear, but it had almost $100 \%$ similarity with the ITS sequence published by Lepelletier et al. (2014) (KF359485).

In the case of $\beta$-tubulin, ours is the first reported sequence of the Parvilucifera genus. The phylogenetic analysis places $P$. sinerae in the Perkinsozoa clade, in agreement with the previously reported tree topologies of closely related genera (Leander 2003, Saldarriaga 2003).

\section{Phenotypic characterization}

Twelve strains of the parasitoid $P$. sinerae were phenotypically characterized according to host invasion, zoospore success, rate of infection, $K_{m}$, maximum infection level, and maturation time (Table 3). The results are presented in detail below.

Strain variability in host invasion, infection rate, $K_{m}$, and maximum infection

Fig. 3 shows the invasion curves obtained within 90 min following the inoculation of host cells with 12 different strains of $P$. sinerae. The number of invaded host cells increased exponentially during the first $30 \mathrm{~min}$ and stabilized thereafter. The final percentages $(25-75 \%)$ of invaded cells differed depending on the parasitoid strain. Maximum infection, infection rate, and $K_{m}$ were obtained using the data from the host invasion curves and the Michaelis-Menten equation (Table 3). All parameters indicated high strain-dependent variability, with maximum infection levels ranging from 27.04 to $107.15 \%$, infection rates from 0.02 to 1.6 invaded cells $\mathrm{min}^{-1}$, and $K_{m}$ values from 3.29 to $44.4 \mathrm{~min}$. Fig. 4 shows the range of variability for each phenotypic character within the studied strains. 


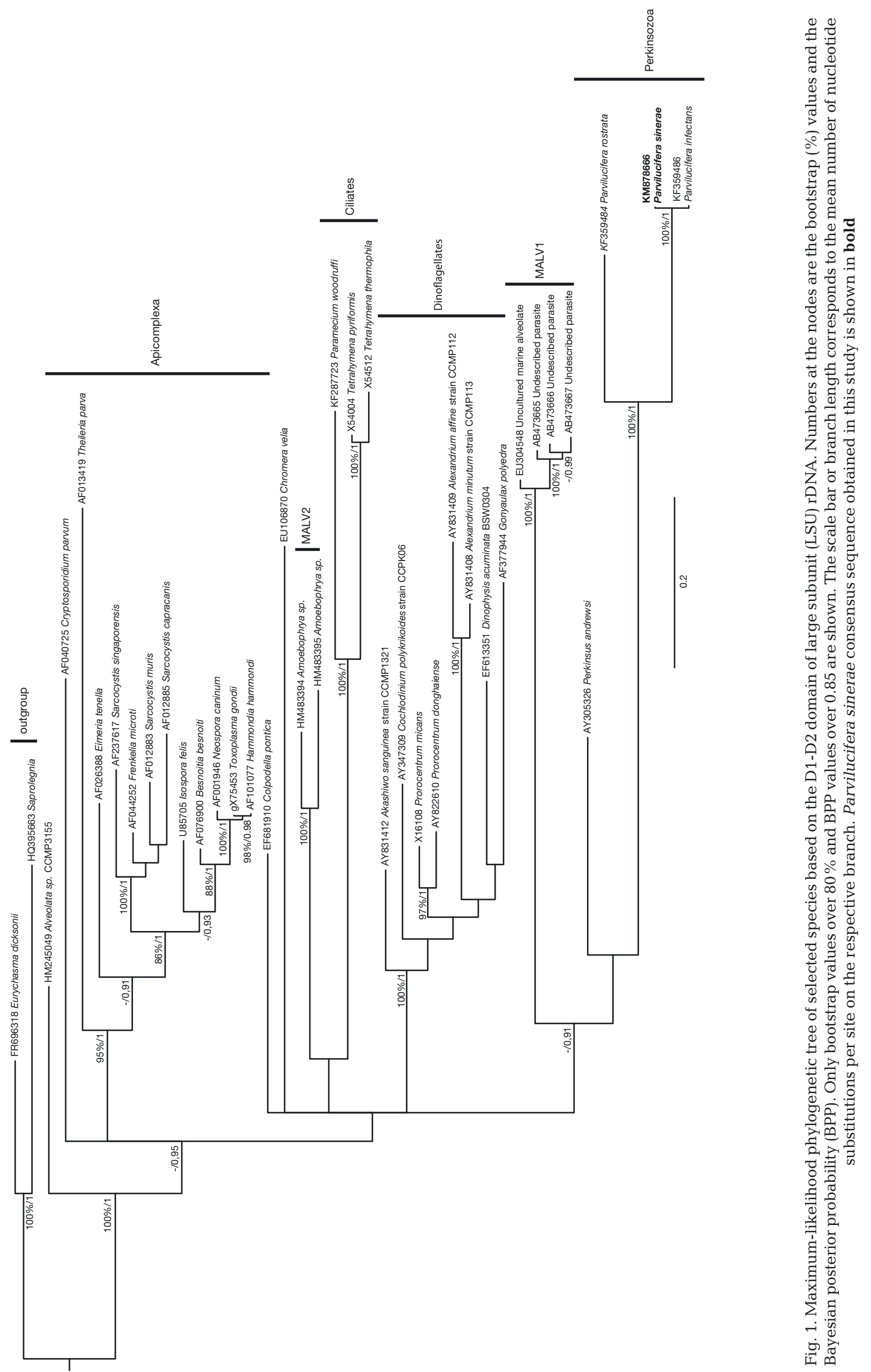




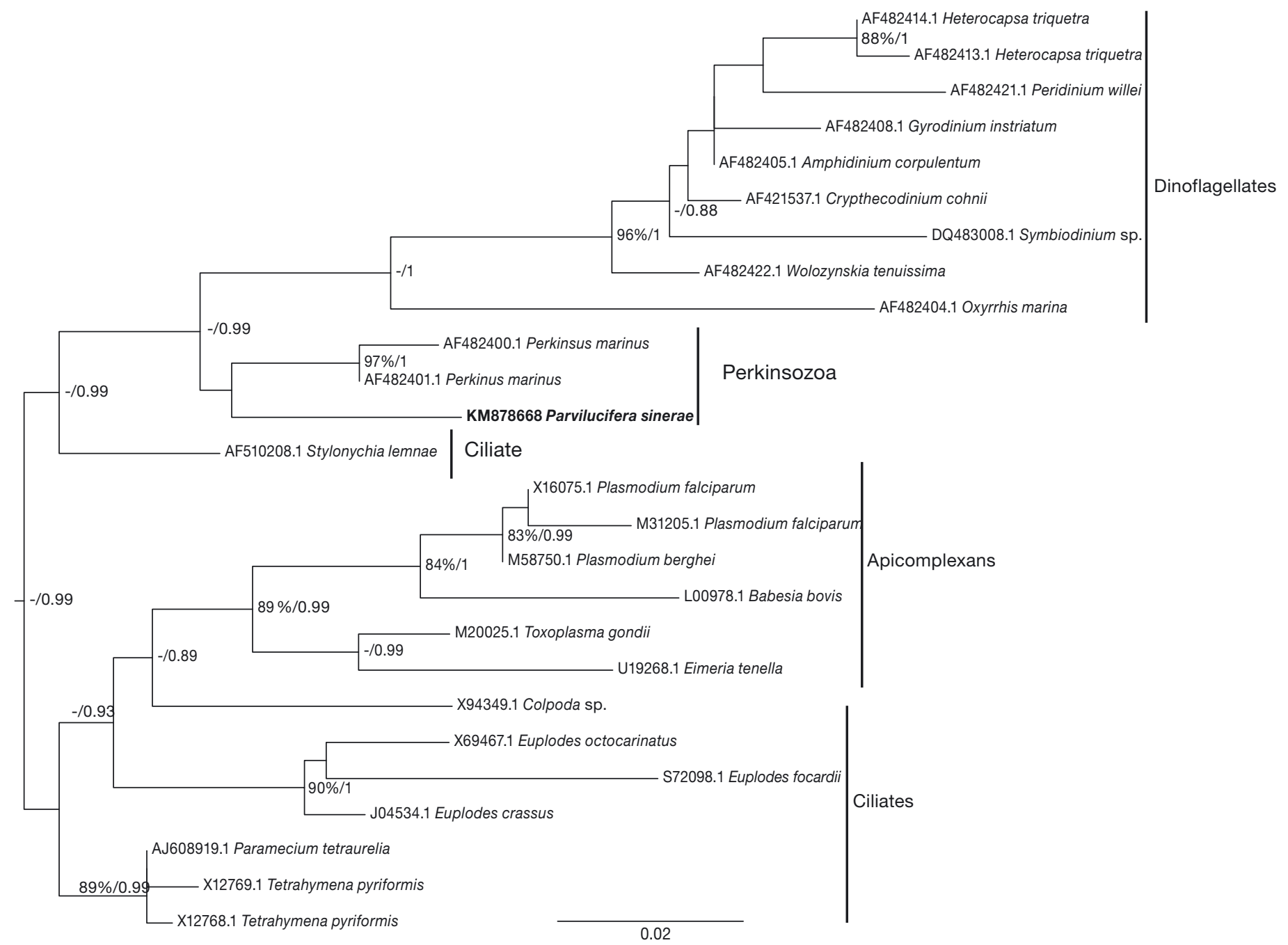

Fig. 2. Maximum-likelihood phylogenetic tree of selected species based on $\beta$-tubulin sequences (387 aa). Numbers at the nodes are the bootstrap values (\%) and the Bayesian posterior probability (BPP). Only bootstrap values over $80 \%$ and BPP values over 0.85 are shown. The scale bar or branch length corresponds to the mean number of nucleotide substitutions per site on the respective branch. Parvilucifera sinerae consensus sequence obtained in this study is shown in bold

Table 2. Genetic similarities between the Parvilucifera sinerae ribosomal regions determined in this study (accession numbers in bold) and the sequences of Parvilucifera species obtained from GenBank. The numbers show the percentage of genetic similarity between the sequences of each species. ITS: internal transcribed spacer, SSU: small subunit, LSU: large subunit; nd: no data

\begin{tabular}{|lccrc|}
\hline $\begin{array}{l}\text { \% of genetic } \\
\text { similarity }\end{array}$ & $\begin{array}{c}\text { P. rostrata } \\
\text { (Lepelletier et al. 2014) }\end{array}$ & $\begin{array}{c}\text { P. prorocentri } \\
\text { (Hoppenrath \& Leander 2009) }\end{array}$ & $\begin{array}{c}\text { P. infectans } \\
\text { (Norén et al.1999) }\end{array}$ & $\begin{array}{c}\text { P. infectans } \\
\text { (Lepelletier et al. 2014) }\end{array}$ \\
\hline $\begin{array}{l}\text { ITS P. sinerae } \\
\text { KM878665 }\end{array}$ & 44.7 & nd & nd & 99.8 \\
SSU P. sinerae & KF359483 & & & KF359485 \\
KM878667 & 86.6 & 79.4 & 98.7 & 100 \\
LSU P. sinerae & KF359483 & FJ424512 & AF133909 & KF359485 \\
KM878666 & KF359484 & nd & Ko & 100 \\
\end{tabular}


Table 3. Phenotypic parameters of the 12 strains of Parvilucifera sinerae analyzed, sorted by their percent host invasion at 90 min. The dashed lines divide the 3 groups obtained in the multi-dimensional scaling analysis. N: number of replicates for each strain, $K_{m}$ : half-maximal infection

\begin{tabular}{|c|c|c|c|c|c|c|c|c|c|c|c|c|c|c|c|}
\hline P21 & 3 & 107.2 & 9.0 & 69.9 & 8.4 & 44.4 & 8.1 & 0.989 & 7.6 & 2.2 & 0.058 & 0.01 & 1 & 99.9 & 0.2 \\
\hline P70 & 2 & 101.6 & 17.8 & 73.7 & 1.3 & 24.2 & 11.9 & 0.911 & 2.4 & 0.4 & 1.612 & 0.17 & 1 & 94.9 & 1.0 \\
\hline P55 & 2 & 96.3 & 17.6 & 55.2 & 11.3 & 61.3 & 21.6 & 0.969 & 2.4 & 0.6 & 0.963 & 0.07 & 1 & 83.7 & 1.8 \\
\hline P11 & 4 & 87.4 & 8.2 & 71.3 & 9.8 & 14.5 & 4.4 & 0.959 & 1.5 & 0.5 & 0.101 & 0.06 & 2 & 94.5 & 4.8 \\
\hline P33 & 3 & 78.3 & 5.1 & 62.0 & 9.1 & 21.4 & 4.1 & 0.983 & 23.8 & 5.3 & 0.087 & 0.03 & - & - & - \\
\hline P13 & 4 & 71.1 & 3.7 & 59.9 & 8.3 & 10.3 & 2.1 & 0.979 & 8.9 & 5.5 & 0.071 & 0.04 & 1 & 93.9 & 3.7 \\
\hline P67 & 2 & 62.2 & 3.4 & 51.9 & 2.4 & 22.2 & 3.5 & 0.987 & 7.7 & 2.0 & 0.793 & 0.05 & 1 & 96.9 & 1.4 \\
\hline P1 & 2 & 58.1 & 2.9 & 49.0 & 4.9 & 15.2 & 2.7 & 0.982 & 20.0 & 5.8 & 0.065 & 0.0 & 1 & 93.1 & 1.2 \\
\hline P20 & 3 & 41.3 & 1.8 & 40.5 & 3.2 & 5.9 & 1.3 & 0.963 & 2.9 & 0.3 & 0.077 & 0.03 & 2 & 98.8 & 1.1 \\
\hline P10 & 3 & 39.9 & 1.5 & 36.1 & 6.8 & 10.1 & 1.4 & 0.989 & 3.3 & 0.5 & 0.122 & 0.11 & 2 & 87.2 & 1.6 \\
\hline
\end{tabular}

Strain variability in zoospore success rates

In this study, the success rate was defined as the number of zoospores germinating from 1 sporangium and able to invade new host cells, thus initiating a new round of infection. The zoospore success rates were below $10 \%$, except for strain P33 and P1 (Table 3).

\section{Statistical similarity analysis}

Three groups were identified in the group average cluster analysis and SIMPROF test $(\alpha=0.01)$. They are referred to here as A, B, and C and exhibited $90 \%$ similarity. ANOSIM analysis based on similarities among the strains with respect to the above-described parameters showed significant differences in the global test $(\mathrm{p}=0.0001)$. The correspondent pairwise tests identified significant differences between groups $\mathrm{B}$ and $\mathrm{C}(\mathrm{p}=0.012)$ and between groups B and A ( $\mathrm{p}=$ 0.012). No significant differences were found between groups $\mathrm{C}$ and $\mathrm{A}$, likely due to the low number of data. Multi-dimensional scaling analysis (0.07 stress; Fig. 5) allowed visualization of the 3 groups obtained in the SIMPROF test. The SIMPER test showed that the average similarity within each group was mainly explained $(>40 \%$ ) by the maximum infection levels, followed by $K_{m}(>25 \%)$ and zoospore success (>15\%). Therefore, group A consisted of strains with the highest levels, group B included those strains with intermediate levels, and group C comprised the strains with the lowest levels of infection. The average dissimilarity among groups was $10 \%$ between groups B and $\mathrm{C}$ and between groups $\mathrm{B}$ and $\mathrm{A}$, and about $16 \%$ between groups $\mathrm{A}$ and $\mathrm{C}$.
Strain variability in sporangium germination and maturation time

For all of the strains, once dark sporangia were observed, most of the sporangia hatched within 1-2 d, thereby activating previously dormant zoospores. The strains reached maturity on Day 4 post-infection, consistent with the time (3-4 d) required for infection by the previously analyzed strain P1 (Table 1). Based on an infection process of 3-4 d, the generation time of $P$. sinerae was therefore estimated to be 5-6 d.

The sporangium germination rate was between 83 and $99 \%$. Newly released zoospores were able to begin a new round of infection once the maturation process was completed. The maturation parameters of strains P33 and P31 unfortunately could not be assessed because the cultures became contaminated during the experiment and eventually died.

\section{DISCUSSION}

Overall, our results provide evidence of (1) the suitability of the genetic markers tested (SSU, LSU, ITS, and $\beta$-tubulin) for the phylogenetic characterization of Parvilucifera sinerae, (2) the similarity in the genetic regions studied between geographically and temporally distant strains for the markers analyzed, and (3) the physiological variability within geographically and temporally different strains of $P$. sinerae. The results are discussed in detail below.

The genera Parvilucifera and Perkinsus are closely related according to all genetic markers analyzed in this study. However, the node for this group was always poorly supported (<80\% bootstrap support), 

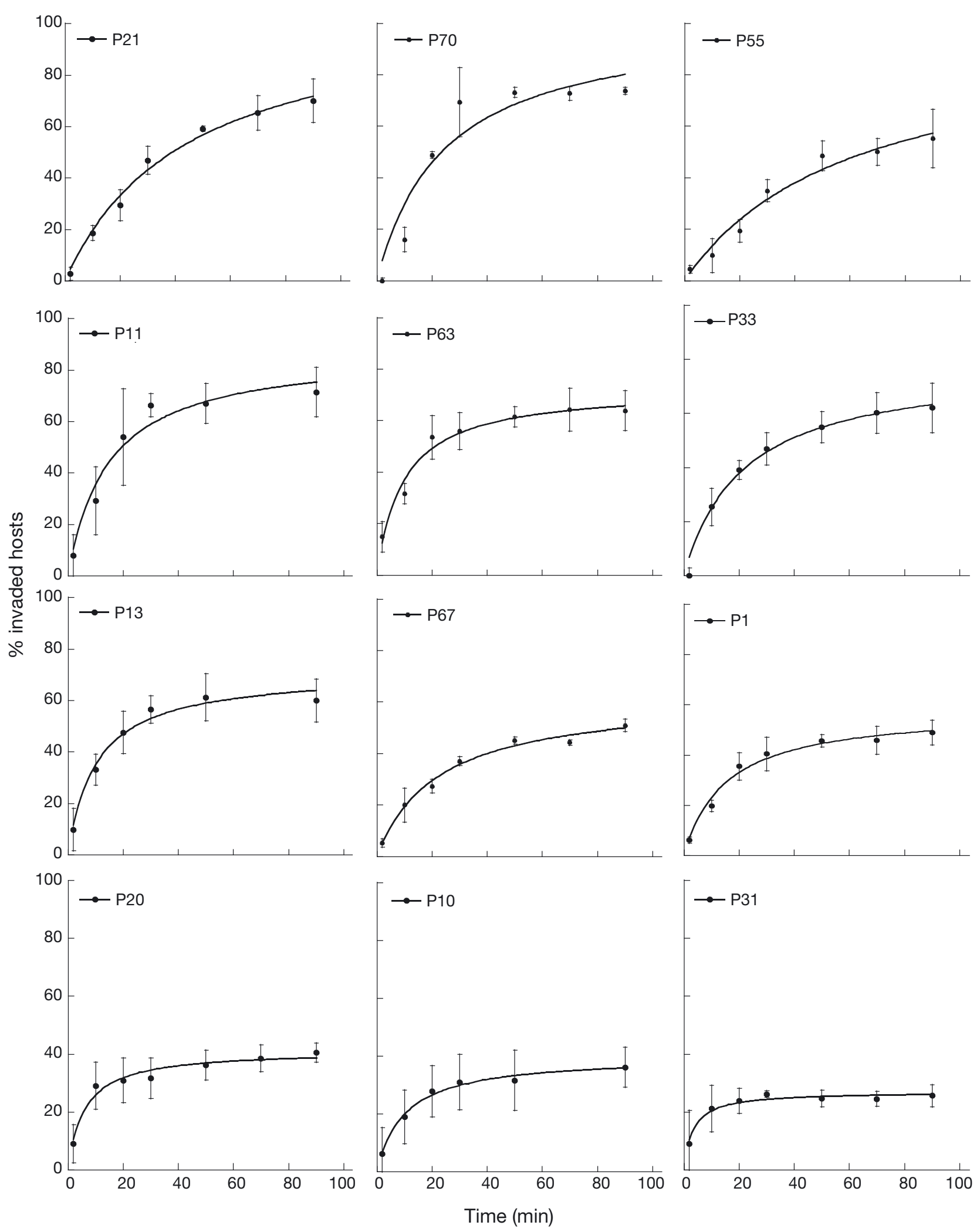

Fig. 3. Invasion curves of the 12 strains of Parvilucifera sinerae, determined over a period of 90 min. Error bars are the standard deviation of 3 replicates. The data were fitted to a Michaelis-Menten curve to obtain half-maximal infection $\left(K_{m}\right)$ and predicted maximum infection (see Table 3) 


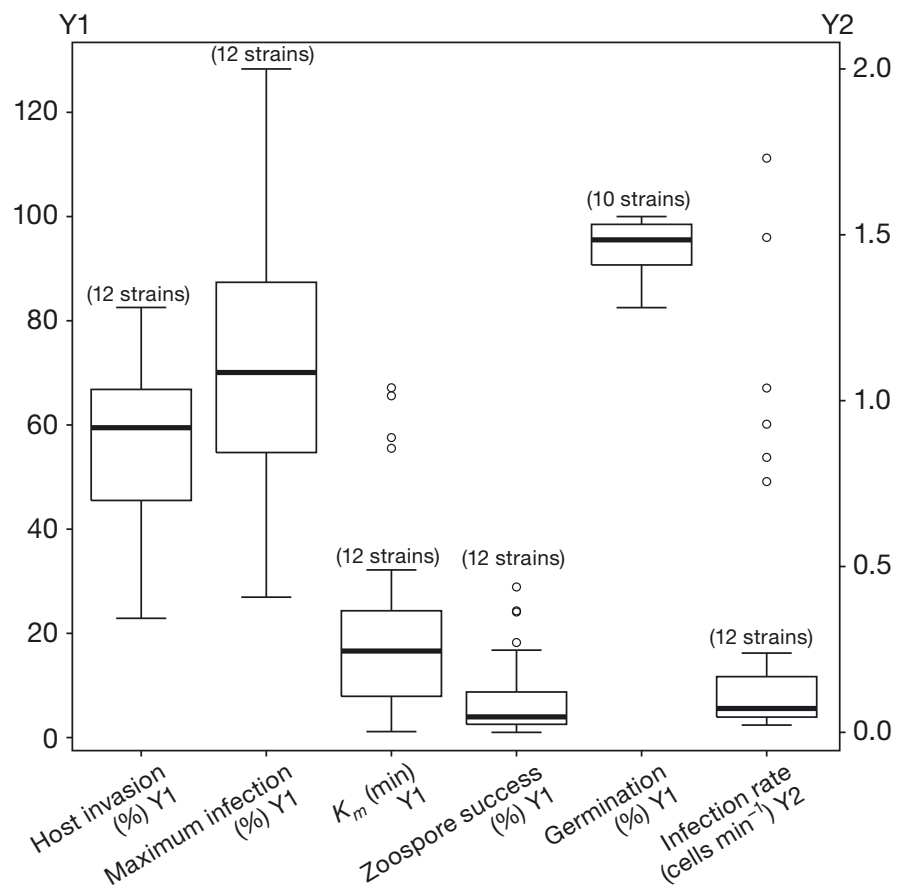

Fig. 4. Range of variability for each parameter. The number of strains of Parvilucifera sinerae analyzed is indicated in parentheses. Host invasion $(\mathrm{N}=33)$, maximum infection $(\mathrm{N}=33)$, half-maximal infection $\left(K_{m}, \mathrm{~N}=33\right)$, zoospore success $(\mathrm{N}=33)$, and sporangium germination $(\mathrm{N}=30)$ are shown on the left $y$-axis, and the infection rate $(\mathrm{N}=33)$ is on the right $y$-axis. The bottom and top of the box are the first and third quartiles, and the band inside the box is the median. Whiskers are the maximum and the minimum and the outliers are marked as circles

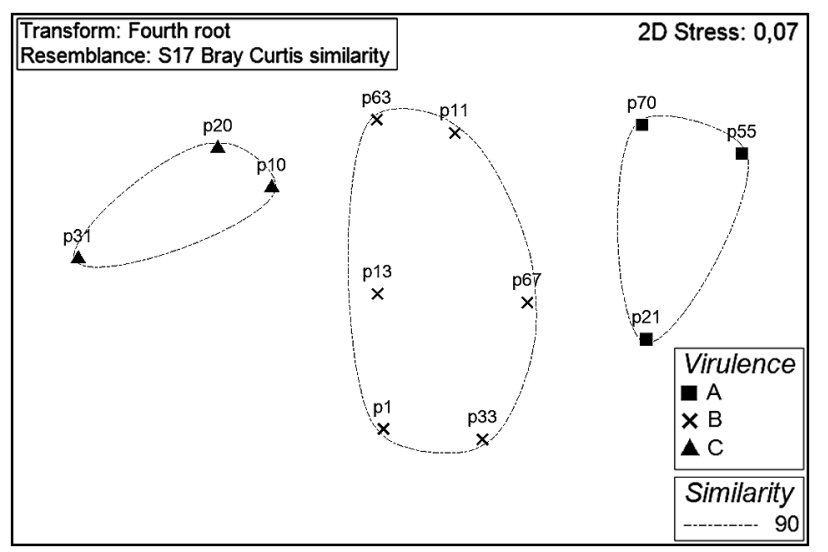

Fig. 5. Multi-dimensional scaling of Parvilucifera sinerae strains (2 dimensions are shown). Fourth-root data transformation, Bray-Curtis similarity, 0.07 stress. Three groups (A, $B$, and $C$ ) were identified in the group average cluster analysis and SIMPROF test $(\alpha=0.01)$. Group A consisted of strains with the highest levels of infection (virulence), group $B$ included those strains with intermediate levels, and group $\mathrm{C}$ comprised the strains with the lowest levels. Similarity boundary of $90 \%$ is based on phenotypic traits raising questions about assigning both parasite genera to the division Perkinsozoa, as proposed by Norén et al. (1999). Further phylogenetic information on closely related organisms is needed to clarify this relationship.

Our LSU rDNA phylogenetic analysis placed the studied $P$. sinerae strains and $P$. infectans in the same clade. Note that the $2 \mathrm{SSU}$ sequences available from P. infectans (AF133909, KF359485) are not 100\% identical. Indeed, 1 of them (KF359485) has $100 \%$ of genetic similarity to the sequence obtained for our strains of $P$. sinerae (Table 2). Lepelletier et al. (2014)

0.5 tentatively assigned $P$. infectans to their strains based on the morphological characteristics of this species, such as cytoplasmatic infections in thecate dinoflagellates and the shape and ornamentation of processes, although their sequence only had a $98.7 \%$ similarity with the available $P$. infectans sequence. They assigned their LSU rDNA and ITS sequences accordingly. All our isolates belonged to P. sinerae, since the strain used to genetically (Figueroa et al. 2008) and morphologically (Garcés \& Hoppenrath 2010) describe this species was also included in our study (strain P1), and all our strains had $100 \%$ identity to the ribosomal and $\beta$-tubulin genes of $P$. sinerae. Nonetheless, the relationship between $P$. sinerae and $P$. infectans remains to be clarified in light of the high levels of genetic and morphological similarity reported for these 2 species (Garcés \& Hoppenrath 2010, Lepelletier et al. 2014).

The considerable similarity between $P$. sinerae and $P$. infectans is consistent with the high level of similarity of the ITS regions of the different species belonging to the closely related genus Perkinsus, as previously reported (Coss et al. 2001, Brown et al. 2004, Burreson et al. 2005), but contrasts with the large genetic difference in the phylogenetic position of Parvilucifera prorocentri compared to other Parvilucifera species (Hoppenrath \& Leander 2009, Lepelletier et al. 2014). Our $\beta$-tubulin sequence is the first published protein sequence for the genus Parvilucifera, and it differs by $\sim 5 \%$ from the sequences obtained from the closest species, Perkinsus marinus (AF482400, AF482401).

The identity in both the ribosomal and the $\beta$-tubulin genes of our $P$. sinerae strains, collected from different geographic areas and from host blooms occurring in different years, precluded the use of these markers in assessing intra-specific diversity. Furthermore, despite the frequently reported large variation in the lengths and sequences of the ITS between many species and clades of protists (Thompson et al. 1999, Som et al. 2000, Brown et al. 2004, Logares 
et al. 2007, Hamilton et al. 2010, Schmid-Hempel \& Tognazzo 2010), a high degree of similarity in the ITSs of different strains, as was the case in our study, has been recognized (Connell 2000, Loret et al. 2002, Tengs et al. 2003, Logares et al. 2008). Indeed, the divergence of some markers may be even faster than the divergence of those examined herein (Orr \& Smith 1998, Logares et al. 2008). Accordingly, for our $P$. sinerae strains, it would be of interest to sequence their mitochondrial DNA (mtDNA), an approach that has been used in the phylogenetic reconstruction of different organisms (Zhang et al. 2011, Orr et al. 2012, Raho et al. 2013) and in whole-genome characterizations. However, mitochondrial genes are not always useful in species discrimination, as in the case for the dinoflagellate genus Ostreopsis (Penna et al. 2014). We recently attempted to amplify the $\operatorname{cox}$ and cob genes of mtDNA using primers from the closest genus, Perkinsus (Zhang et al. 2011). Unfortunately, neither of these regions could be amplified, probably due to limiting amounts of DNA and/or the failure of the primers. Thus, further efforts are needed to identify an appropriate, fast-evolving gene that would allow the reliable determination of the populationlevel variability of $P$. sinerae.

Despite the lack of variability in the genetic markers analyzed between geographically and temporally distant strains of the parasitoid $P$. sinerae, some of those strains exhibit high levels of phenotypic variability.

The inter-strain variability of the $12 P$. sinerae strains with respect to host invasion, zoospore success, infection rate, $K_{m}$, maximum infection, and germination was confirmed by their phenotypic characterization. The parameters with higher variability, i.e. $K_{m}$ and maximum infection levels, were those with a greater dependence on host-parasitoid interactions, whereas the parameters with less variability, i.e. maturation time and sporangia germination, were related to the endogenous properties of each parasitoid strain.

Virulence can be defined as the negative impact exerted by a parasitoid on its host and is generally considered to depend on many factors, such as the rates of transmission and parasitoid proliferation (Bushek \& Allen 1996). Additional determinants include those analyzed in this study: host invasion, infection rate, and zoospore success in encountering a host cell. The 3 groups (A, B, C) identified by multidimensional scaling were distinguished mainly by their different percentages of host invasion and by their different $K_{m}$ values, thus reflecting differences in strain virulence. However, the virulence pattern of the 3 groups could not be ascribed to host-cell bloom appearance or to the location or the year of parasitestrain isolation. Rather, parasitoid strains from the same bloom significantly differed in their virulence traits (e.g. P31, P33, and P21 in 2011; P70, P67, and P55 in 2013, Fig. 5), suggesting that the same population differs phenotypically in certain characteristics. Only a limited number of studies have examined phenotypic variation within parasite populations. Coats \& Park (2002) found differences in the generation time of different strains of the Amoebophrya ceratii complex, implying the evolution of different survival strategies within a single population. Thus, strain variability among $P$. sinerae populations may likewise be an adaption aimed at maintaining fitness. In host-parasite systems, fitness can be measured by means of net growth/mortality rates, as analyzed by Råberg et al. (2014). Other measures of fitness include the total abundance of a host or its parasites during the experiment, the maximum proportion of infected hosts, or success in subsequent rounds of zoospore infection, as measured in our study. These differences suggest variations in ecological strategies among parasitoid strains, but this remains to be confirmed at the population level by a larger sampling effort and including the assessment of variability of hosts from the same bloom. In any case, this parasitoid variability could be explained by the fact that dinoflagellate host populations are reported as not clonal (Alpermann et al. 2006, Van Dolah et al. 2009) and consequently could induce variability in their parasitoids. For example, phenotypic variability was previously reported for several bloom-forming microalgal species (Loret et al. 2002, Calbet et al. 2011, Sampedro et al. 2013). Overall, recognition of the physiological variability in host-parasite relationships is an important consideration if they are to be exploited in the mitigation of HABs.

In summary, our results provide the first phylogenetic information available for some genetic markers of the genus Parvilucifera and are the first to show a lack of variability in the genetic markers analyzed among different strains of a Parvilucifera species. Additionally, our results provide evidence of the previously unrecognized physiological variability of protist parasites.

The lack of variability in genetic markers usually variable (ITS, $\beta$-tubulin) could reflect a recent dispersion of this species, as reported in other protist species (Logares et al. 2008), or that Alexandrium minutum is a recent and not primary host to which this parasitoid has not shown adaptation yet. In marine waters, even in the absence of physical barriers that 
prevent gene flow (Finlay 2002), several forms of selective pressure may influence parasite evolution (Gandon \& Michalakis 2002). In particular, the high genetic variability within some protists, see e.g. Tahvanainen et al. (2012), may well determine a similarly high degree of genetic variation in their parasites that allows the latter to overcome evolving host defenses (Jokela et al. 2009). This host-parasite model suggests the continuous adaptation of both components and thus the preservation of parasite fitness. In a recent study (Råberg et al. 2014), host resistance and parasite virulence were statistically shown to depend on genotype-specific interactions, of both the parasite and the host, although according to other authors, this interaction exclusively depends on phenotypic traits (Eklöf et al. 2013). Clearly, hostparasite interactions are complex and, together with the implications of high intraspecific diversity in natural host populations, remain to be fully elucidated.

Acknowledgements. This study was supported by the Spanish Ministry of Science and Innovation through the project PARAL (CTM2009-08399). Microalgal and parasitoid cultures were provided by the culture collection of CCVIEO (Vigo, Spain). R.I.F. was funded by the Crafoord Foundation (Sweden, contract 2011:0882). We thank E. Flo (ICM, CSIC) for help with the statistical analyses.

\section{LITERATURE CITED}

Alpermann TJ, John UE, Medlin LK, Edwards KJ, Hayes PK, Evans KM (2006) Six new microsatellite markers for the toxic marine dinoflagellate Alexandrium tamarense. Mol Ecol Notes 6:1057-1059

- Brown GD, Hudson KL, Reece KS (2004) Multiple polymorphic sites at the ITS and ATAN loci in cultured isolates of Perkinsus marinus. J Eukaryot Microbiol 51:312-320

Burreson EM, Reece KS, Dungan CF (2005) Molecular, morphological, and experimental evidence support the synonymy of Perkinsus chesapeaki and Perkinsus andrewsi. J Eukaryot Microbiol 52:258-270

> Bushek D, Allen SK Jr (1996) Host-parasite interactions among broadly distributed populations of the eastern oyster Crassostrea virginica and the protozoan Perkinsus marinus. Mar Ecol Prog Ser 139:127-141

Calbet A, Bertos M, Fuentes-Grünewald C, Alacid E, Figueroa R, Renom B, Garcés E (2011) Intraspecific variability in Karlodinium veneficum: growth rates, mixotrophy, and lipid composition. Harmful Algae 10:654-667

> Chambouvet A, Morin P, Marie D, Guillou L (2008) Control of toxic marine dinoflagellate blooms by serial parasitic killers. Science 322:1254-1257

Chambouvet A, Alves-de-Souza C, Cueff V, Marie D, Karpov S, Guillou L (2011) Interplay between the parasite Amoebophrya sp. (Alveolata) and the cyst formation of the red tide dinoflagellate Scrippsiella trochoidea. Protist 162:637-649

Clarke KR, Gorley RN (2006) PRIMER v 6: user manual/ tutorial. PRIMER-E, Plymouth
Coats DW, Park MG (2002) Parasitism of photosynthetic dinoflagellates by three strains of Amoebophrya (Dinophyta): parasite survival, infectivity, generation time, and host specificity. J Phycol 38:520-528

- Collins NE, Allssopp BA (1999) Theileria parva ribosomal internal transcribed spacer sequences exhibit extensive polymorphism and mosaic evolution: application to the characterization of parasites from cattle and buffalo. Parasitology 118:541-551

Connell LB (2000) Nuclear ITS region of the alga Heterosigma akashiwo (Chromophyta: Raphidophyceae) is identical in isolates from Atlantic and Pacific basins. Mar Biol 136:953-960

> Coss CA, Robledo JAF, Ruiz GM, Vasta GR (2001) Description of Perkinsus andrewsin. sp. isolated from the Baltic clam (Macoma balthica) by characterization of the ribosomal RNA locus, and development of a species-specific PCR-based diagnostic assay. J Eukaryot Microbiol 48: 52-61

> Darriba D, Taboada GL, Doallo R, Posada D (2011) ProtTest 3: fast selection of best-fit models of protein evolution. Bioinformatics 27:1164-1165

> Darriba D, Taboada GL, Doallo R, Posada D (2012) jModelTest 2: more models, new heuristics and parallel computing. Nat Methods 9:772

Edvardsen B, Shalchian-Tabrizi K, Jakobsen KS, Medlin LK, Dahl E, Brubak S, Paasche E (2003) Genetic variability and molecular phylogeny of Dinophysis species (Dinophyceae) from Norwegian waters inferred from single cell analyses of rDNA. J Phycol 39:395-408

Eklöf A, Jacob U, Kopp J, Bosch J and others (2013) The dimensionality of ecological networks. Ecol Lett 16:577-583

> Fast NM, Xue L, Bingham S, Keeling PJ (2002) Re-examining alveolate evolution using multiple protein molecular phylogenies. J Eukaryot Microbiol 49:30-37

Figueroa RI, Garcés E, Massana R, Camp J (2008) Description, host-specificity, and strain selectivity of the dinoflagellate parasite Parvilucifera sinerae sp. nov. (Perkinsozoa). Protist 159:563-578

> Finlay BJ (2002) Global dispersal of free-living microbial eukaryote species. Science 296:1061-1063

> Gandon S, Michalakis Y (2002) Local adaptation, evolutionary potential and host-parasite coevolution: interactions between migration, mutation, population size and generation time. J Evol Biol 15:451-462

> Garcés E, Hoppenrath M (2010) Ultrastructure of the intracellular parasite Parvilucifera sinerae (Alveolata, Myzozoa) infecting the marine toxic planktonic dinoflagellate Alexandrium minutum (Dinophyceae). Harmful Algae 10:64-70

> Garcés E, Alacid E, Bravo I, Fraga S, Figueroa RI (2013) Parvilucifera sinerae (Alveolata, Myzozoa) is a generalist parasitoid of dinoflagellates. Protist 164:245-260

Guillard RRL (1995) Culture methods. In: Hallegraeff GM, Anderson DM, Cembella AD (eds) Manual on harmful marine microalgae. IOC Manuals and Guides No. 33. UNESCO, Paris, p 45-62

Hall TA (1999) BioEdit: a user-friendly biological sequence alignment editor and analysis program for Windows 95/98/NT. Nucleic Acids Symp Ser 41:95-98

> Hamilton KM, Morritt D, Shaw PW (2010) Genetic diversity of the crustacean parasite Hematodinium (Alveolata, Syndinea). Eur J Protistol 46:17-28

Hoppenrath M, Leander BS (2009) Molecular phylogeny of Parvilucifera prorocentri (Alveolata, Myzozoa): insights 
into perkinsid character evolution. J Eukaryot Microbiol 56:251-256

> Jokela J, Dybdahl M, Lively C (2009) The maintenance of sex, clonal dynamics, and host-parasite coevolution in a mixed population of sexual and asexual snails. Am Nat 174:S43-S53

Katoh K, Misawa K, Kuma K, Miyata T (2002) MAFFT: a novel method for rapid multiple sequence alignment based on fast Fourier transform. Nucleic Acids Res 30: 3059-3066

Leander BS (2003) Phylogeny of gregarines (Apicomplexa) as inferred from small-subunit rDNA and beta-tubulin. Int J Syst Evol Microbiol 53:345-354

Leander BS, Hoppenrath M (2008) Ultrastructure of a novel tube-forming, intracellular parasite of dinoflagellates: Parvilucifera prorocentri sp. nov. (Alveolata, Myzozoa). Eur J Protistol 44:55-70

> Lepelletier F, Karpov SA, Le Panse S, Bigeard E, Skovgaard A, Jeanthon C, Guillou L (2014) Parvilucifera rostrata sp. nov. (Perkinsozoa), a novel parasitoid that infects planktonic dinoflagellates. Protist 165:31-49

> Lin S, Zhang H, Spencer DF, Norman JE, Gray MW (2002) Widespread and extensive editing of mitochondrial mRNAS in dinoflagellates. J Mol Biol 320:727-739

> Logares R, Rengefors K, Kremp A, Shalchian-Tabrizi K and others (2007) Phenotypically different microalgal morphospecies with identical ribosomal DNA: a case of rapid adaptive evolution? Microb Ecol 53:549-561

Logares R, Daugbjerg N, Boltovskoy A, Kremp A, LaybournParry J, Rengefors K (2008) Recent evolutionary diversification of a protist lineage. Environ Microbiol 10: 1231-1243

> Lohr JN, Laforsch C, Koerner H, Wolinska J (2010) A Daphnia parasite (Caullerya mesnili) constitutes a new member of the Ichthyosporea, a group of protists near the animal-fungi divergence. J Eukaryot Microbiol 57:328-336

> Loret P, Tengs T, Villareal A, Singler H and others (2002) No difference found in ribosomal DNA sequences from physiologically diverse clones of Karenia brevis (Dinophyceae) from the Gulf of Mexico. J Plankton Res 24: 735-739

Lymbery AJ (1992) Interbreeding, monophyly and the genetic yardstick: species concepts in parasites. Parasitol Today 8:208-211

Masuda I, Matsuzaki M, Kita K (2010) Extensive frameshift at all AGG and CCC codons in the mitochondrial cytochrome c oxidase subunit 1 gene of Perkinsus marinus (Alveolata; Dinoflagellata). Nucleic Acids Res 38: 6186-6194

Mazzillo FFM, Ryan JP, Silver MW (2011) Parasitism as a biological control agent of dinoflagellate blooms in the California Current System. Harmful Algae 10:763-773

> Medlin L, Elwood HJ, Stickel S, Sogin ML (1988) The characterization of enzymatically amplified eukaryotic 16Slike rRNA-coding regions. Gene 71:491-499

> Montagnes DJS, Chambouvet A, Guillou L, Fenton A (2008) Responsibility of microzooplankton and parasite pressure for the demise of toxic dinoflagellate blooms. Aquat Microb Ecol 53:211-225

> Norén F, Moestrup Ø, Rehnstam-Holm AS (1999) Parvilucifera infectans Norén et Moestrup gen. et sp. nov. (Perkinsozoa phylum nov.): a parasitic flagellate capable of killing toxic microalgae. Eur J Protistol 35:233-254

> Orr MR, Smith TB (1998) Ecology and speciation. Trends Ecol Evol 13:502-506
Orr RJS, Murray SA, Stüken A, Rhodes L, Jakobsen KS (2012) When naked became armored: An eight-gene phylogeny reveals monophyletic origin of theca in dinoflagellates. PLoS ONE 7:e50004

Park MG, Yih W, Coats DW (2004) Parasites and phytoplankton, with special emphasis on dinoflagellate infections. J Eukaryot Microbiol 51:145-155

Park MG, Kim S, Shin EY, Yih W, Coats DW (2013) Parasitism of harmful dinoflagellates in Korean coastal waters. Harmful Algae 30:S62-S74

Penna A, Battocchi C, Capellacci S, Fraga S, Aligizaki K, Lemée R, Vernesi C (2014) Mitochondrial, but not rDNA, genes fail to discriminate dinoflagellate species in the genus Ostreopsis. Harmful Algae 40:40-50

> Poulin R, Thomas F (1999) Phenotypic variability induced by parasites: extent and evolutionary implications. Parasitol Today 15:28-32

Råberg L, Alacid E, Garcés E, Figueroa RI (2014) The potential for arms race and Red Queen coevolution in a protist host-parasite system. Ecol Evol 4:4775-4785

Raho N, Rodríguez F, Reguera B, Marín I (2013) Are the mitochondrial cox1 and cob genes suitable markers for species of Dinophysis Ehrenberg? Harmful Algae 28: $64-70$

Reece KS, Siddall ME, Burreson EM, Graves JE (1997) Phylogenetic analysis of Perkinsus based on actin gene sequences. J Parasitol 83:417-423

> Robledo JAF, Wright AC, Marsh AG, Vasta GR (1999) Nucleotide sequence variability in the nontranscribed spacer of the rRNA locus in the oyster parasite Perkinsus marinus. J Parasitol 85:650-656

> Robledo JAF, Coss CA, Vasta GR (2000) Characterization of the ribosomal RNA locus of Perkinsus atlanticus and development of a polymerase chain reaction-based diagnostic assay. J Parasitol 86:972-978

Ronquist F, Teslenko M, van der Mark P, Ayres DL and others (2012) MrBayes 3.2: efficient bayesian phylogenetic inference and model choice across a large model space. Syst Biol 61:539-542

> Saldarriaga JF (2003) Multiple protein phylogenies show that Oxyrrhis marina and Perkinsus marinus are early branches of the dinoflagellate lineage. Int J Syst Evol Microbiol 53:355-365

Sampedro N, Franco JM, Zapata M, Riobó P and others (2013) The toxicity and intraspecific variability of Alexandrium andersonii Balech. Harmful Algae 25:26-38

Schmid-Hempel R, Tognazzo M (2010) Molecular divergence defines two distinct lineages of Crithidia bombi (Trypanosomatidae), parasites of bumblebees. J Eukaryot Microbiol 57:337-345

Scholin CA, Herzog M, Sogin M, Anderson DM (1994) Identification of group and strain specific genetic markers for globally distributed Alexandrium (Dinophyceae): sequence analysis of a fragment of the LSU rRNA gene. J Phycol 30:999-1011

Skovgaard A (2014) Dirty tricks in the plankton: diversity and role of marine parasitic protists. Acta Protozool 53: 51-62

Skovgaard A, Massana R, Balague V, Saiz E (2005) Phylogenetic position of the copepod-infesting parasite Syndinium turbo (Dinoflagellata, Syndinea). Protist 156: 413-423

Som I, Azam A, Bhattacharya A, Bhattacharya S (2000) Inter- and intra-strain variation in the 5.8 ribosomal RNA and internal transcribed spacer sequences of Entamobea 
hystolytica and comparison with Entamobea dispar, Entamobea moshkovskii and Entamobea invadens. Int J Parasitol 30:723-728

Stamatakis A (2006) RAxML-VI-HPC: maximum likelihoodbased phylogenetic analyses with thousands of taxa and mixed models. Bioinformatics 22:2688-2690

Tahvanainen P, Alpermann TJ, Figueroa RI, John U and others (2012) Patterns of post-glacial genetic differentiation in marginal populations of a marine microalga. PLoS ONE 7:e53602

Tengs T, Bowers HA, Glasgow HB, Burkholder JM, Oldach DW (2003) Identical ribosomal DNA sequence data from Pfiesteria piscicida (Dinophyceae) isolates with different toxicity phenotypes. Environ Res 93:88-91

Thompson JN (1987) Symbiont induced speciation. Biol J Linn Soc 32:385-393

Thompson RCA, Constantine CC, Morgan UM (1999) Overview and significance of molecular methods: What role for molecular epidemiology? Parasitology 117: 161-175

Toth GB, Norén F, Selander E, Pavia H (2004) Marine dinoflagellates show induced life-history shifts to escape parasite infection in response to water-borne signals. Proc R Soc Lond B Biol Sci 271:733-738
Van Dolah FM, Lidie KB, Monroe EA, Bhattacharya D, Campbell L, Doucette GJ, Kamykowski D (2009) The Florida red tide dinoflagellate Karenia brevis: new insights into cellular and molecular processes underlying bloom dynamics. Harmful Algae 8:562-572

White TJ, Bruns T, Lee S, Taylor J (1990) Amplification and direct sequencing of fungal ribosomal RNA genes for phylogenetics. In: Innis M, Gelfand D, Sninsky J, White T (eds) PCR protocols: a guide to methods and applications. Academic Press, Orlando, FL, p 315-322

Wolinska J, Giessler S, Koerner H (2009) Molecular identification and hidden diversity of novel Daphnia parasites from European lakes. Appl Environ Microbiol 75: 7051-7059

Yih W, Coats DW (2000) Infection of Gymnodinium sanguineum by the dinoflagellate Amoebophrya sp.: effect of nutrient environment on parasite generation time, reproduction, and infectivity. J Eukaryot Microbiol 47: 504-510

> Zhang H, Campbell DA, Sturm NR, Dungan CF, Lin S (2011) Spliced leader RNAs, mitochondrial gene frameshifts and multi-protein phylogeny expand support for the genus Perkinsus as a unique group of alveolates. PLoS ONE 6:e19933

\section{Appendix}

Table A1. PCR temperature profiles to amplify the genetic markers analyzed. SSU: small subunit, LSU: large subunit, ITS: internal transcribed spacer

\begin{tabular}{|c|c|c|c|}
\hline Region & PCR steps & Temperature profile & Primers (reference) \\
\hline SSU rRNA & $\begin{array}{l}\text { Denaturing } \\
\text { Cycles of denaturing } \\
\text { Annealing } \\
\text { Extension } \\
\text { Final extension }\end{array}$ & $\begin{array}{l}94^{\circ} \mathrm{C}, 5 \mathrm{~min} \\
30 \mathrm{cycles} \text { of } 45 \mathrm{~s} \text { at } 94^{\circ} \mathrm{C} \\
1 \mathrm{~min} \text { at } 55^{\circ} \mathrm{C} \\
72^{\circ} \mathrm{C}, 3 \mathrm{~min} \\
72^{\circ} \mathrm{C}, 10 \mathrm{~min}\end{array}$ & EukA and EukB (Medlin et al. 1988) \\
\hline LSU rRNA & $\begin{array}{l}\text { Denaturing } \\
\text { Cycles of denaturing } \\
\text { Annealing } \\
\text { Extension } \\
\text { Final extension }\end{array}$ & $\begin{array}{l}95^{\circ} \mathrm{C} 5 \mathrm{~min} \\
40 \mathrm{cycles} \text { of } 20 \mathrm{~s} \text { at } 95^{\circ} \mathrm{C} \\
30 \mathrm{~s} \text { at } 55^{\circ} \mathrm{C} \\
72^{\circ} \mathrm{C}, 1 \mathrm{~min} \\
72^{\circ} \mathrm{C}, 10 \mathrm{~min}\end{array}$ & D1R and D2C (Scholin et al. 1994) \\
\hline ITS & $\begin{array}{l}\text { Denaturing } \\
\text { Cycles of denaturing } \\
\text { Annealing } \\
\text { Extension } \\
\text { Final extension }\end{array}$ & $\begin{array}{l}95^{\circ} \mathrm{C}, 5 \mathrm{~min} \\
35 \mathrm{cycles} \text { of } 1 \mathrm{~min} \text { at } 95^{\circ} \mathrm{C} \\
45 \mathrm{~s} \text { at } 55^{\circ} \mathrm{C} \\
1 \mathrm{~min} 15 \mathrm{~s} \text { at } 72^{\circ} \mathrm{C} \\
72^{\circ} \mathrm{C}, 7 \mathrm{~min}\end{array}$ & ITS1 and ITS4 (White et al. 1990) \\
\hline$\beta$-tubulin & $\begin{array}{l}\text { Denaturing } \\
\text { Cycles of denaturing } \\
\text { Annealing } \\
\text { Extension } \\
\text { Final extension }\end{array}$ & $\begin{array}{l}95^{\circ} \mathrm{C}, 5 \mathrm{~min} \\
35 \mathrm{cycles} \text { of } 45 \mathrm{~s} \text { at } 95^{\circ} \mathrm{C} \\
45 \mathrm{~s} \text { at } 48^{\circ} \mathrm{C} \\
1 \mathrm{~min} 30 \mathrm{~s} \text { at } 72^{\circ} \mathrm{C} \\
72^{\circ} \mathrm{C}, 7 \mathrm{~min}\end{array}$ & $\begin{array}{l}\text { Fw 5'- ATY GGN GCC AAG TTC TGG GAR GT-3' } \\
\text { Rev 5'-CTT GAT RTT GTT BGG GAT CCA CTC-3' } \\
\text { (designed in the present study) }\end{array}$ \\
\hline
\end{tabular}

Editorial responsibility: Fereidoun Rassoulzadegan, Villefranche-sur-Mer, France
Submitted: June 11, 2015; Accepted: August 12, 2015

Proofs received from author(s): October 4, 2015 